Apidologie, 1981, 12 (4), 377-382.

\title{
BIOLOGY OF HONEYBEE SPERMATOZOA. 3. EFFECT OF AMINO ACIDS AND CATALASE ON RESPIRATION AS MEASURED BY THE CARTESIAN DIVER TECHNIQUE
}

\author{
Laiq Ram VERMA* \\ Institut für Bienenkunde (Polytechnische Gesellschaft) \\ der J.W. Goethe-Universität Frankfurt a. M., \\ Fachbereich Biologie, Im Rothkopf 5, 6370 Oberursel/Ts., F.R.G.
}

\section{SUMMARY}

The addition of exogenous amino acids such as L-lysine, L-arginine, L-glutamic acid and enzyme Catalase increased the rate of oxygen consumption of honeybee spermatozoa significantly, supporting the earlier view that these amino acids and catalase has beneficial effect on motility and survival of spermatozoa.

\section{INTRODUCTION}

Previously we demonstrated that addition of arginine, lysine and enzyme catalase to the tris buffer diluent $(p \mathrm{H}: 7.19)$ showed beneficial effect on motility and survival of honeybee (Apis mellifera L.) spermatozoa (VERMA, 1978 a). Even after 9 months of storage at $14{ }^{\circ} \mathrm{C}$, spermatozoa mixed with these diluents could be reactivated and normal spiral pattern of sperm motility was observed. With the addition of catalase, more number of spermatozoa reached spermatheca after inseminating the queen bee with semen mixed to this diluent (VERMA, 1978 a). Amino acid analysis by NovaK et al. (1960) showed that arginine, lysine and glutamic acid content of honeybee spermatozoa and seminal plasma was quite high. These studies suggest that like mammalian spermatozoa, the presence of amino acid and catalase facilitate the survival of honeybee spermatozoa.

In the present investigation, the effect of added exogenous amino acids such as $\mathrm{L}$ lysine, L-arginine, L-glutamic acid and enzyme catalase on respiratory metabolism of honeybee spermatozoa was studied with Cartesian diver respirometry.

* Present address : Department of Bio-Sciences, H.P. University, Simla-171005, India. 


\section{MATERIALS AND METHODS}

Semen was collected from sexually mature drones using the method of RurTNER (1975). The procedure for washing the spermatozoa free from seminal plasma, as developed earlier by VERMA (1978 b) was followed. Semen was collected directly into a small disposable capillary tubes attached to the insemination syringe and mixed with tris buffer diluent $(p \mathrm{H}: 7.19)$. Semen was diluted approximately 1 in 3 with the diluent to give a final volume of about $40 \mu \mathrm{l}$ in a glass capillary tube. These samples were then centrifuged at 4000 R.P.M. for $25 \mathrm{~min}$. The supernatant was withdrawn and replaced by an equal volume of tris buffer diluent containing amino acids or catalase. Oxygen consumption was measured with the Cartesian diver technique. This apparatus was made by the author with minor modifications, according to the method of Hotler (1943). The detailed procedure for measuring gas exchange of insect spermatozoa with Cartesian diver technique is given previously (Verma and Shuel, 1973; Verma, 1978 b). Oxygen consumption was expressed as micro-litres of oxygen taken by $10^{8}$ spermatozoa per unit time. Neubauer haemocytometer was used for determining the concentration of spermatozoa. Only these measurements were considered in which at least $95 \%$ spermatozoa were motile.

\section{RESULTS}

Arginine, lysine and glutamic acid were added to the tris buffer diluent at $100 \mathrm{mg} / \mathrm{l}$ each respectively. Concentration of Catalase (20\% Behringwerke) was $2 \mu \mathrm{l} / \mathrm{ml}$ of tris buffer diluent. Our previous results showed that these concentrations of amino acids and catalase had beneficial effect on sperm motility and survival (Verma, 1978 a).

In each case, $2 \mu \mathrm{l}$ of washed sperm suspension was mixed to an equal volume of tris buffer diluent containing the above concentrations of amino acids and catalase. The final volume of reaction mixture in the diver bulb was $4 \mu 1$ and divers were incubated at $32{ }^{\circ} \mathrm{C}$ aerobically.

Respiration results (Fig. 1 and Table 1) show that addition of tris buffer diluent containing lysine, arginine and glutamic acid to the washed sperm suspension increased the rate of oxygen uptake significantally as compared to washed samples with no amino acids. The oxygen consumption due to the addition of catalase to the washed spermatozoa was significantally higher from that of the control samples. In all experiments, respiration rates were uniform only for a limited period of time and declined gradually during the later stages of experiments.

\section{DISCUSSION}

The results reported here show that addition of all the three amino acids produced a significant increase in the respiratory activity of honeybee spermatozoa (Fig. 1 and Table 1). Similar results were also obtained with sea urchin spermatozoa (TYLER, 1953; TYLER and RoTHSCHILD, 1951) supporting the view that amino acids have a beneficial effect on motility and viability of invertebrate spermatozoa. 


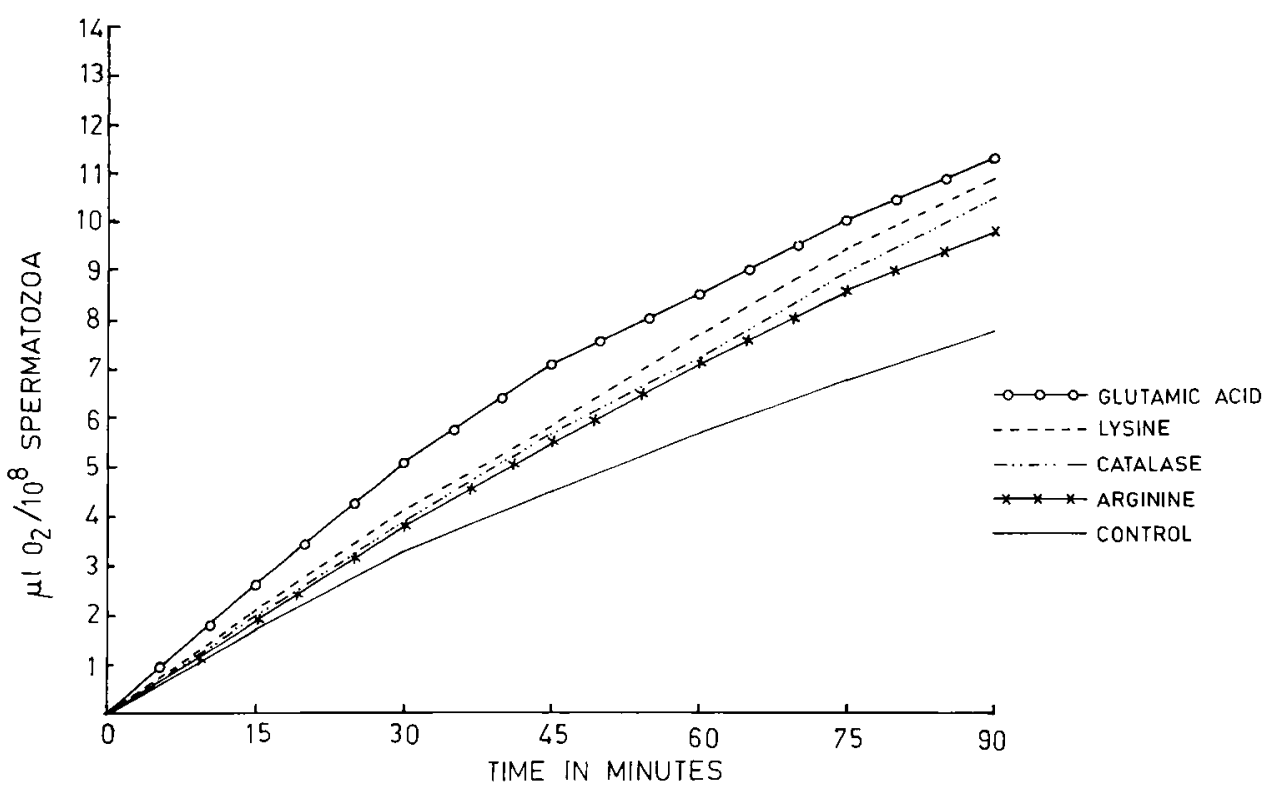

FIG. 1. - Effect of amino acids and catalase on oxygen consumption.

Spermatozoa of high animals (bull, ram and boar etc.) are capable of utilizing free amino acids as extracellular oxidizable substrates for the aerobic metabolism of spermatozoa. Many free amino acids present in the extracellular environment of mammalian spermatozoa either enhance of prolong the respiratory activity of washed spermatozoa (MANN, 1964). Thus honeybee spermatozoa are like that of higher animals as they can possibly also oxidize amino acids and may use them as potential substrate for exogeneous respiration.

In the present experiments, addition of catalase to tris buffer diluent increased the rate of oxygen uptake significantally. High activity of catalase has been reported in sea-urch in spermatozoa (RoTHSCHILD, 1948). This enzyme decomposes hydrogen peroxide, which is produced by oxidative deamination of amino acids by the mammalian spermatozoa and accumulation of hydrogen peroxide is considered toxic to sperm cells because it inhibits sperm fructolysis (Tosic and WALTON, 1950).

Received for publication. in A ugust 1981.

\section{ACKNOWLEDGEMENTS}

The author wishes to thank Prof. Dr. F. Ruttner for providing the working space in his laboratory. The work was made possible by a research fellowship to the author by Alexander von Humboldt Stiftung. 


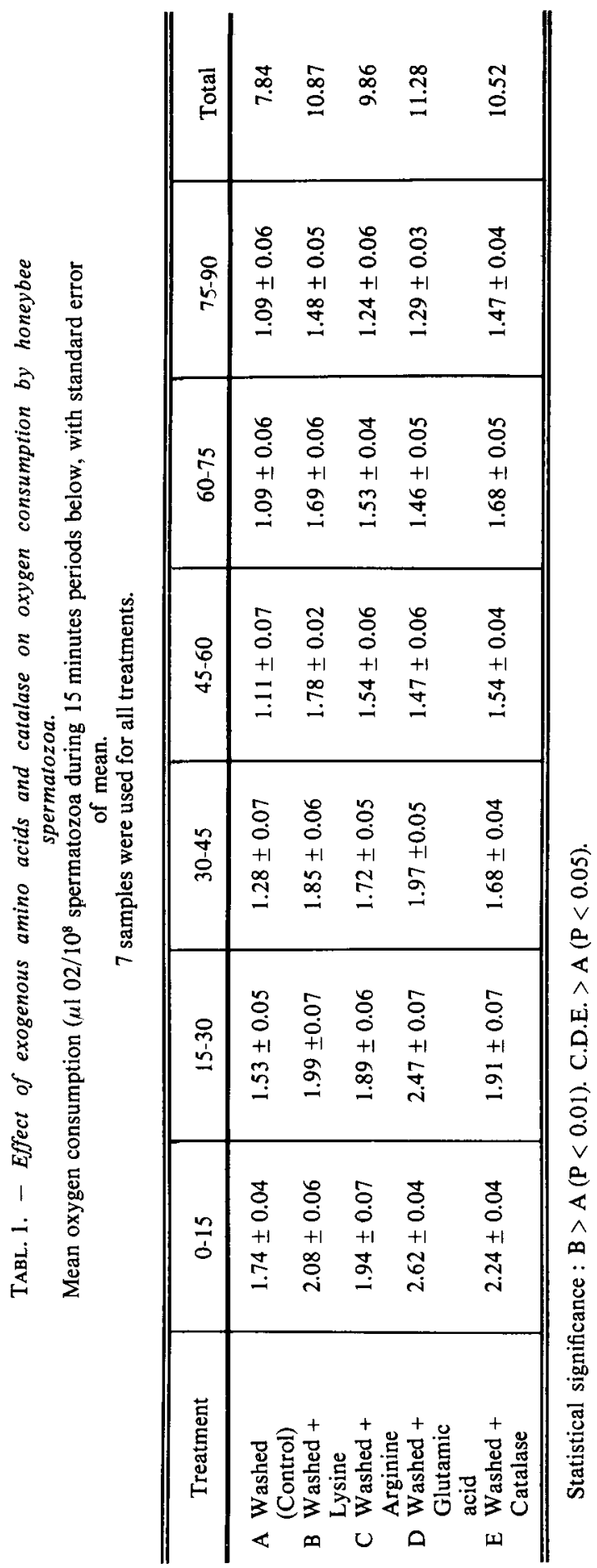




\section{RÉSUMÉ \\ BIOLOGIE DES SPERMATOZOIDES D'ABEILLES. 3. ACTION DES ACIDES ANIMÉS ET DE LA CATALASE SUR LA RESPIRATION MESURÉE PAR LA TECHNIQUE AU LUDION}

Dans ce travail on a étudié par la méthode au ludion l'action d'acides aminés tels que la L-lysine, la L-arginine et l'acide L-glutamique et de la catalase sur le métabolisme respiratoire des spermatozoïdes de l'abeille. Le sperme a été directement prélevé sur des mâles sexuellement mûrs dans de fins capillaires de verre attachés à la seringue d'insémination et il a été mélangé au diluant tampon tris. Après l'avoir empli de $10 \mu \mathrm{l}$ de sperme et de $30 \mu \mathrm{l}$ de diluant tampon tris, on a fermé le capillaire avec une capsule stérile en caoutchouc. On a centrifugé les échantillons à 4000 R.P.M. durant $25 \mathrm{mn}$. La partie surnageante a été retirée et la suspension de sperme centrifugée mélangée au même volume de diluant contenant les acides aminés ou la catalase. La consommation d'oxygène a été mesurée avec un appareil au ludion fabriqué par l'auteur et exprimée par le nombre de $\mu \mathrm{l}$ d' $\mathrm{O}_{2}$ absorbés par $10^{8}$ spermatozoïdes par unité de temps. La concentration en spermatozoïdes a été déterminée avec un haemocytomètre Neubauer.

La consommation en oxygène des suspensions de sperme mélangé au diluant tampon tris contenant de la L-lysine, de la L-arginine et de l'acide L-glutamique a été significativement plus élevée que celle des échantillons lavés auxquels on n'avait pas ajouté de substrat. De même l'addition de catalase a accru de façon significative les taux respiratoires. Ces résultats confirment l'idée émise aupravant selon laquelle ces acides aminés et la catalase ont un effet bénéfique sur la motilité et la survie des spermatozoïdes d'abeilles.

\section{ZUSAMMENFASSUNG}

BIOLOGIE DER SPERMATOZOEN DER HONIGBIENE.

3. EINFLUSS VON AMINOSÄUREN UND KATALASE AUF DEN MIT HILFE DER METHODE DES KARTESIANISCHEN TAUCHERS GEMESSENEN RESPIRATORISCHEN STOFFWECHSEL

In dieser Arbeit wird der Einfluss der Zugabe von Aminosäuren wie L-Lysin, L-Arginin und LGlutaminsäure und des Enzyms Katalase auf den respiratorischen Stoffwechsel von Spermatozoen der Honigbiene mit Hilfe der Methode des Kartesianischen Tauchers untersucht. Der Samen wurde von sexuell reifen Drohnen direkt in feine Glaskapillaren aufgenommen, die an einer Inseminationsspritze befestigt waren und mit einem Trispuffer-Verdünner gemischt. Nach Füllung mit $10 \mu 1$ Samen und $30 \mu 1$ TrispufferVerdünner wurde die Kapillare mit einer sterilen Gummikappe verschlossen. Die Proben wurden anschliessend für 25 min. mit 4000 R.P.M. zentrifugiert. Der Überstand wurde abgegossen und die zentrifugierte Samensuspension mit dem gleichen Volumen der Aminosäure- oder Katalase-Lösung gemischt. Der Sauerstoffverbrauch wurde mit dem vom Autor hergestellten Kartesianischen TaucherApparat gemessen und als Anzahl der $\mu 1 \mathrm{O}_{2}$ angegeben, die von $10^{8}$ Spermatozoen pro Seiteinheit aufgenommen wurden. Die Konzentration der Spermatozoen wurde mit einem Neubauer-Haemozytometer bestimmt.

Die Sauerstoffaufnahme der Spermien-Suspension, gemischt mit einem Trispuffer, der L-Lysin, LArginin oder L-Glutaminäure enthielt, war signifikant höher als der von gewaschenen Proben ohne Zusatz dieses Substrates. Auch der Zusatz des Enzyms Katalase erhöhte die Respirations-Rate signifikant. Dadurch wird die frûher geäusserte Ansicht gestützt, dass diese Aminosäuren und Katalase einen günstigen Einfluss auf die Beweglichkeit und das Überleben der Spermatozoen der Honigbiene haben.

\section{REFERENCES}

Holter H., 1943. - Technique for the Cartesian diver. C.r. Trav. Lab. Carlsberg Series Chim. 24, 397 478.

MANN T., 1964. - The biochemistry of semen and of the male reproductive tract. London. Methuen. 
NovaK A. F., Blum M. S., TABer S. III., Louiso J. A., 1960. - Separation and determination of seminal plasma and sperm amino acids of honeybee Apis mellifera. Ann. Ent. Soc. Amer. 53, 841-843.

RothsChILD Lord, 1948. - The physiology of sea urchin spermatozoa. Lack of movement of semen. J. exp. Biol. 25, 344-352.

Ruttner F., 1975. - The instrumental insemination of the queen bee. Bucharest. Apimondia Printing House.

Tos̀ıC J., WALton A., 1950. - Metabolism of spermatozoa. The formation and elimination of hydrogen peroxide and its effects on motility and survival. Biochem. j.47, 199-212.

Tyler A., 1953. - Prolongation of life-span of sea urchin spermatozoa, and improvement of the fertilization reaction, by treatments of spermatozoa and eggs with metal-chelating agents (amino acids, versene, D.E.D.T.C., Oxine, Curpron). Biol. Bull. Woods Hole, 104, 224-239.

TYler A., Rothschild Lord., 1951. - Metabolism of sea urchin spermatozoa and induced anaerobic motility in solutions of amino acids. Proc. Soc. Exp. Biol., N.Y.; 76, 52-58.

VERMA L. R., 1978 a. - Biology of honeybee (Apis mellifera L.) spermatozoa 1. Effect of different diluents on motility and survival. Apidologie, 9, 167-174.

VERMA L. R., 1978 b. - Biology of honeybee spermatozoa. 2. Effect of washing and of sugars on respiration as measured by the Cartesian diver technique. J. Apic. Res. 14, 113-118.

Verma L. R., Shuel R. W., 1973. - Respiratory metabolism of semen of the honeybee Apis mellifera.J. Insect Physiol. 19, 97-103. 